\title{
GENETIC DIVERSITY OF Dendrocalamus asper IN JAVA REVEALED BY RAPD MARKERS
}

\author{
Anto Rimbawanto'
}

\begin{abstract}
Dendrocalamus asper is one of the most widely use and widely distributed bamboo species in Indonesia. A genetic conservation plot has been established to maintain genetic diversity of the species. A total of 115 samples were collected from 12 sites throughout Java. Genetic diversity was revealed using 31 RAPD primers producing 64 polymorphic bands. A total of 81 different multi-locus genotypes (genets) were identified between 115 samples. The total number of multi-locus genotypes in all populations ranged from 3 to 9 (mean 6.5), indicating that all populations consisted of multiple genotypes. Mean genetic diversity was 0.04 , (ranging from the lowest 0.009 in Kuningan population to the highest 0.144 in Purwokerto population). The Simpson's diversity index indicated that the most population composed of unique genotype. Geographical differences did not correlate with genetic cluster.
\end{abstract}

Keywords: Clonal diversity, genetic diversity, RAPD, Dendrocalamus asper.

\section{INTRODUCTION}

Bamboo is one of the most important multi-purpose plant species in the planet earth. South and South-East Asia have significant bamboo resources and have been referred to as the centre of bamboo germplasms with as many as 45 genera and 750 species out of total 75 genera and 1250 species in the world (Dransfield and Widjaja, 1995).

Dendrocalamus asper is one of the most widely used and widely distributed bamboo ispecies in Indonesia (Dransfield and Widjaja, 1995). The culms are used for building material for houses as they have thick walls and are very strong and durable. The species is found in Sumatera, Java, Sulawesi and Irian Jaya. Despite its wide utilization, little is known about the genetic aspects of the species. Understanding the genetic diversity is essential for genetic conservation of the species.

Conservation of sexually reproduced plants must concerned with the number of genetic individuals (genets) present in the populations for assessing genetic factors such as inbreeding depression and genetic drift (Ellstrand and Elam, 1993). However, for plants that reproduce clonally, the number of ramets present has no direct correlation with genetic diversity. Therefore study of conservation genetic of clonal plants should assess the proportions of different genets found in a population (Sipes and Wolf, 1997). D. asper is reproduced asexually by its rhizomes. It is postulated that population genetic diversity of the species would be low. The most widely used index for calculation of genetic diversity is $\mathrm{He}$ (expected heterozygosity), which equivalent to $\mathrm{Nei}$ 's unbiased gene diversity $(\mathrm{Nei}, 1977$ ). This

\footnotetext{
Forest Plantation Research and Development Center, Yogyakarta
} 
index also yield accurate estimations for dominant markers such as Random Amplified Polymorphic DNA (RAPD). For asexually reproduced species, the genotypic variation (variation based on number and frequency of individual genets) may be calculated as proportion of distinguished genets $(\mathrm{G} / \mathrm{N})$ and the Simpson's diversity index (Ellstrand and Roose, 1987).

Determining the number of genets in a population of clonal plants has been facilitated by the availability of a range of molecular markers such as RAPD marker. RAPD is a PCRbased marker developed by Williams et al. (1990). It has been widely used in many fields of genetic studies including phylogenetic, parentage identification, cultivar and clone identification and population genetic structure (Jover et al., 2003). Its simplicity and yet good resolution ability for clone identification were among the reasons for using this RAPD marker for the present study. The purpose of the study was to examine the genetic diversity of $D$. asper from a range of population site in Java, Indonesia.

\section{MATERIALS AND METHODS}

\section{a. Materials}

A total of 115 samples were collected from 12 sites throughout Java (Figure 1). Leaf samples were kept in a silica gel in a paper envelope while transporting to the laboratory.

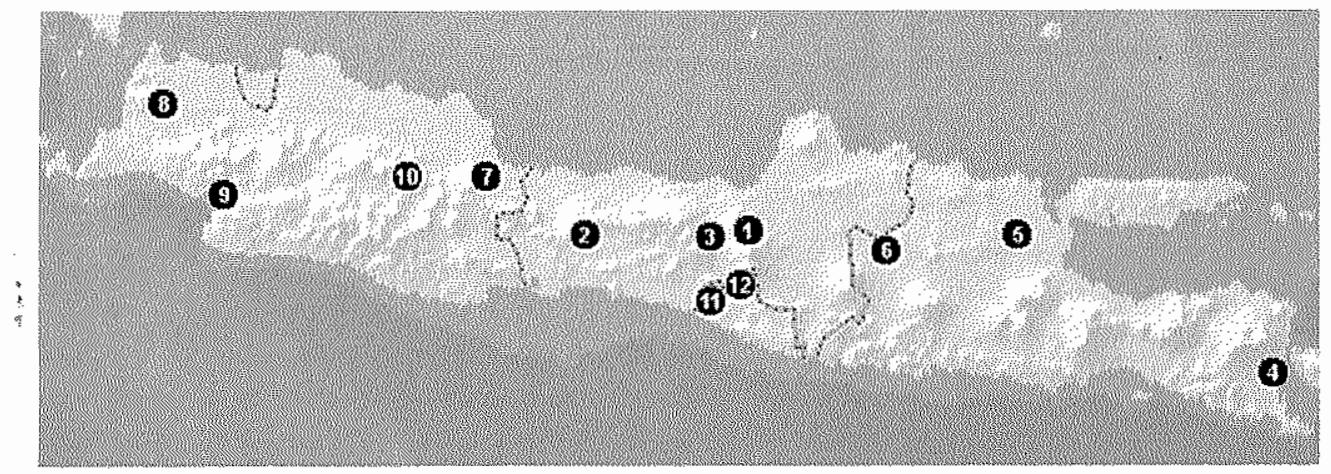

Figure 1. Sampling sites of Dendrocalamus asper used in the genetic study

Remarks: 1. Ambarawa, 2. Purwokerto, 3. Temanggung, 4. Banyuwangi, 5. Lamongan, 6. Ngawi., 7. Kuningan, 8. Pandeglang, 9.Sukabumi, 10 Sumedang, 11. Kulon Progo, 12. Sleman

\section{b. DNA Extraction}

Total genomic DNA was extracted by using a modified (Shiraishi and Watanabe, 1995) CTAB method (Murray and Thompson, 1980). Leaves were grinded in CTAB buffer by employing the MiniBead Beater-8 (BioSpec products) and then incubated for 1 hour at $65^{\circ} \mathrm{C}$. After incubation, $800 \mu \mathrm{l}$ chloroform:isoamylalcohol (24:1) was added to the mixture and mixed by totation for 20 minutes. Centrifuged at $12.000 \mathrm{rpm}$ for 10 minutes then the 
supernatant was removed into new tubes. This step was repeated once with less chloroform : isoamylalcohol $(700 \mu \mathrm{l})$. After this step the supernatant was removed to new tube and then 20 $\mu \mathrm{l}$ sodium acetate was added. DNA was precipitated by adding $650-\mu \mathrm{l}$ isopropanol, centrifuged it at $15.000 \mathrm{rpm}$ for 5 minutes and washed the pellet with $70 \%$ ethanol. The remaining ethanol was removed by vacuum (PerSeptive Biosystems) dried for 3 minutes then $300 \mathrm{\mu l} \mathrm{H}_{2} \mathrm{O}$ was added.

The extracted DNA was then purified using a Wizard DNA Clean-Up System (Promega) according to the manufacturer's instructions.

\section{c. RAPD Primers}

Primers were selected based on the polymorphic nature of the primers. Screening of polymorphic primers was performed to eighty-six random primers (Operon Technologies set $A, G, J, K$ and P) using 6 samples from different populations. Once polymorphic primers were selected they will be used for genetic analysis.

\section{PCR Amplification and Electrophoresis}

PCR reaction was done with GeneAmp 9700 Perkin Elmer in a 101 reaction volume

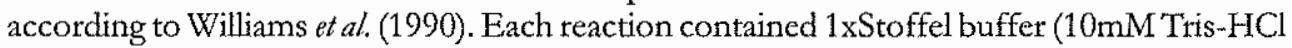
$\mathrm{pH} 8.3$ and $10 \mathrm{mM} \mathrm{KCl}$ ), $0.05 \mathrm{U}$ Taq DNA Polymerase Stoffel Fragment (Applied BioSystem), $3.0 \mathrm{mM} \mathrm{MgCl}, 200 \mathrm{mM}$ each dNTP, $0.25 \mathrm{mM}$ primer and $12.5 \mathrm{ng}$ genomic DNA. DNA amplification was performed at $95^{\circ} \mathrm{C}$ for $1 \mathrm{~min}$, followed by $45 \mathrm{cycles}$ at $95^{\circ} \mathrm{C}$ for 30 second, $37^{\circ} \mathrm{C}$ for 30 second and $72^{\circ} \mathrm{C}$ for 1.5 minutes, and followed by 7 minutes at $72^{\circ} \mathrm{C}$.

PCR product were electrophoresed on $1.5 \%$ agarose gel with $1 \times$ TBE buffer and subjected for 2 hours at $120 \mathrm{~V}$. Detection of PCR product were done by staining with ethidium bromide and photographed using Fotodyne Image Analyzer.

\section{e. Data Analysis}

Data were scored on the presence or absence of amplification products. If a band was present in a genotype it was designated as 1 , if no shared band was present in another genotypes it was designated as 0 . Only intensely stained polymorphic bands were used in the following statistical analyses. Because $D$. asper reproduces vegetatively, we conducted the analyses of clonal diversity within and among populations. The modification of Simpson diversity index (Pielou, 1969) was used for the first measure of clonal diversity $[d=1 \Sigma\{$ (ni)(ni1)) $/(\mathrm{N}(\mathrm{N}-1))\}$ ], where $n_{\mathrm{i}}=$ number of samples with genotypes $i$ and $N$ was the total number of samples. The value of this index ranged between 0 and 1 where the greater the value, the greater the sample diversity.

The second measure of clonal diversity was the "proportion distinguishable" (Ellstrand and Roose, 1987), which is the number of genets $(G)$ relative to the number of samples $(N)$. The clonal fraction i.e. the proportion of samples derived from clonal propagation, was considered for each population as $(N-G) / N$.

Nei's gene diversity (Nei 1973) was constructed using POPGENE 1.32 (Yeh et al., 1999). The same software was used to determine the Nei's (1972) genetic distance for each pair wise combination of populations and then the dendrogram was constructed. 


\section{RESULTS AND DISCUSSIONS}

\section{A. Results}

\section{Primer Screening}

The screening of RAPD primers was carried out to select polymorphic primers (primers that would give informative fragments). The initial screening of 86 random primers resulted 31 primers $(36 \%)$ were polymorphic, while other 55 primers $(64 \%)$ produced only monomorphic bands. Out of these 31 polymorphic primers yielded a total of 64 polymorphic bands. Each primer produced 1 to 4 polymorphic bands (2.0 polymorphic band per primers on average), which ranged in size between $240 \mathrm{bp}$ (OP-G18) and $910 \mathrm{bp}$ (OP$\mathrm{J10)}$.

Of the 64 polymorphic loci observed, the highest $33(51,56 \%)$ polymorphic loci were arised in the Purwokerto population, while the lowest $2(3,12 \%)$ polymorphic loci were occurred in the Kuningan population (Table 3).

\section{Genetic Diversity}

When genotypes of the 64 loci were combined, a total of 81 different multi-locus genotypes (genets) were identified between 115 samples. Among 81 genotypes, 61 (75\%) genotypes were detected only once, and remaining $17(21 \%)$ genotypes were detected more than once. The total number of multi-locus genotypes in all populations ranged from 3 to 9 (mean 6.5), indicating that all populations consisted of multiple genotypes. The proportion of "distinguishable genotypes" (G/N) ranged from 0.300 to 0.900 (mean 0.68 ) with the highest value in the Pandeglang population. The clonal fraction in all populations was $32.17 \%$. The lowest value (10\%) was found in Pandeglang, while highest value $(70 \%)$ was in Kuningan population. The Simpson's diversity index (d) for all populations ranged from 0.510 to 0.978 (mean 0.850 ) (Table 4).

The Nei's gene diversity $(\mathrm{H})$ (Nei, 1973) resulted that the highest value $(0.144)$ found in Purwokerto population, while Kuningan has the lowest $(0.009)$ with mean of gene diversity was 0.04 (Table 4). The UPGMA dendrogram provided a few insights into the genetic clustering of the twelve populations (Figure 3). It is apparent that there was no geographical grouping of the populations in relation to its genetic distance. 
Table 3. The twelve populations of Dendrocalamus asper sampled and summary of clonal diversity results.

\begin{tabular}{|c|c|c|c|c|c|c|c|c|c|}
\hline No. & $\begin{array}{l}\text { Population name } \\
\text { (Locality) }\end{array}$ & $N$ & $H$ & $\begin{array}{c}\text { Genet } \\
\text { sampled } \\
1 \mathrm{x}\end{array}$ & $\begin{array}{l}\text { Genet } \\
\text { sampled } \\
>1 x\end{array}$ & total & $\begin{array}{c}\text { Clonal } \\
\text { fraction } \\
(\%)\end{array}$ & $d$ & $\mathrm{G} / \mathrm{N}$ \\
\hline ! & Ambarawa, Central Java & 10 & $0.0318(12.5 \%)$ & 6 & 2 & 8 & 20.00 & 0.955 & 0.800 \\
\hline 2 & Purwokerto, Central Java & 10 & $0.14433(51.56 \%)$ & 7 & 1 & 8 & 20.00 & 0.933 & 0.800 \\
\hline 3 & Temanggung, Central Java & 5 & $0.0214(6.25 \%)$ & I & 2 & 3 & 40.00 & 0.900 & 0.600 \\
\hline 4 & Banyuwangi, East Java & 10 & $0.03410(15.62 \%)$ & 6 & 1 & 7 & 30.00 & 0.867 & 0.700 \\
\hline 5 & Lamongan, East Java & 10 & $0.0326(9.38 \%)$ & 5 & 1 & 6 & 40.00 & 0.778 & 0.600 \\
\hline 6 & Ngawi, East Java & 10 & $0.0226(9.38 \%)$ & 4 & 2 & 6 & 40.00 & 0.844 & 0.600 \\
\hline 7 & Kuningan, West Java & 10 & $0.0092(3.12 \%)$ & 1 & 2 & 3 & 70.00 & 0.511 & 0.300 \\
\hline 8 & Pandeglang, West Java & 10 & $0.04210(15.62 \%)$ & 8 & 1 & 9 & 10.00 & 0.978 & 0.900 \\
\hline 9 & Sukabumi, West Java & 10 & $0.0267(10.94 \%)$ & 6 & 1 & 7 & 30.00 & 0.867 & 0.700 \\
\hline 10 & Sumedang, West Java & 10 & $0.04410(15.62 \%)$ & 6 & 2 & 8 & 20.00 & 0.955 & 0.800 \\
\hline 11 & Kulon Progo, Jogjakarta & 9 & $0.0479(14.06 \%)$ & 5 & 1 & 6 & 33.33 & 0.833 & 0.667 \\
\hline \multirow[t]{3}{*}{12} & Sleman, Jogjakarta & 11 & $0.0309(14.06 \%)$ & 6 & 1 & 7 & 36.36 & 0818 & 0.636 \\
\hline & Total & 115 & & 61 & 17 & 78 & 32.17 & & \\
\hline & Mean & 9.6 & 0.040 & 5,08 & 1.42 & 6.50 & 32.47 & 0.85 & 0.68 \\
\hline
\end{tabular}

Note: N: number of sample; H; Nei's (1972) gene diversity; P: polymorphic loci; $d$ Simpson's diversity index; $\mathrm{G} / \mathrm{N}$ : proportion of distinguishable

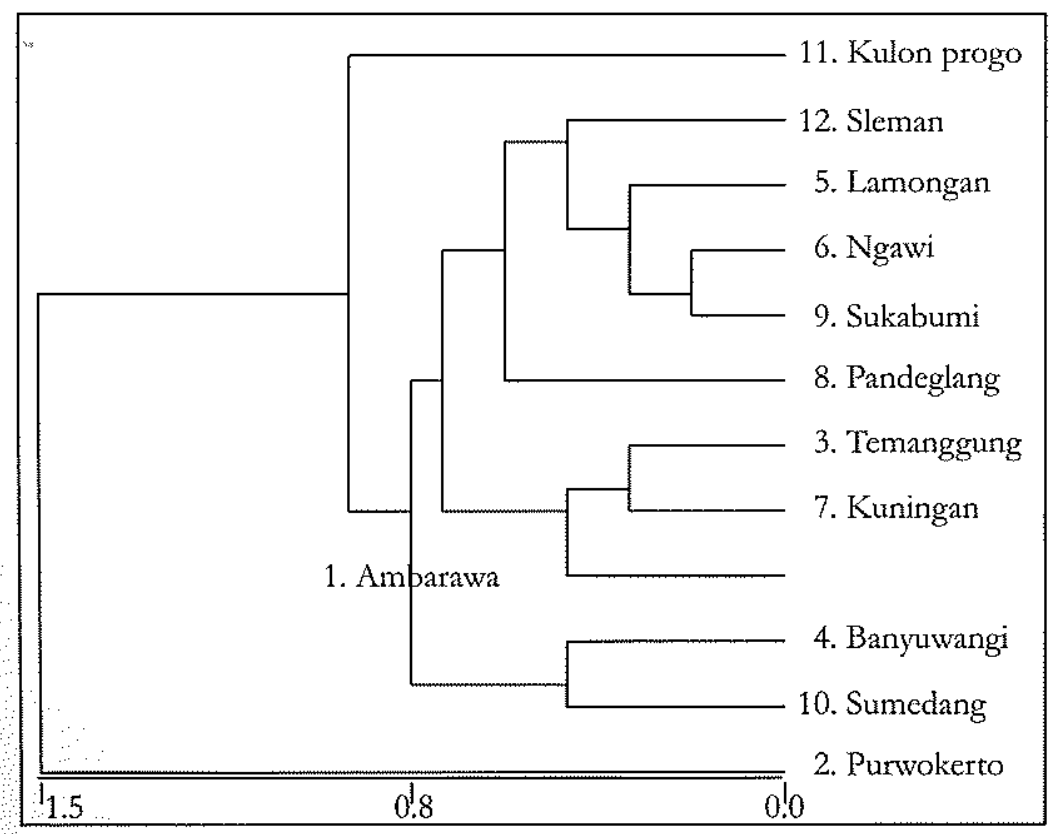

Figure 3. Dendrogram from UPGMA cluster analysis, based on Nei's (1972) genetic distance between the twelve populations of Dendrocalamus asper 


\section{B. Discussion}

The study represents the first application of RAPD markers to characterize the genetic diversity of Dendrocalamus asper in Indonesia. The results indicate that the RAPD technique is a useful tool for analyzing genetic diversity of the bamboo species. Given the asexual reproductive system of the species, the low genetic diversity is normal. The mean expected heterozygosity for $D$. asper $\mathrm{He} 0.040$ is much lower than outcrossed long-lived tree species such as Shorea leprosula (He 0.406; Lee et al., 2000) or other tropical tree species (He 0.125; Hamrick etal., 1992).

Bamboo reproduction is mostly asexual by its thizomes. Most bamboo has gregarious flowering habit in which after flowering bamboo culms die. The rhizomes produce offspring that are identical to the maternal plant and to each other. This reproduction system can affect the genetic structure of a population (Murawski and Hamrick, 1990). Outcrossed, windpollinated species generally have considerably high levels of genetic diversity than selfed or animal-pollinated species with mix-mating system (Hamrick and Godt, 1989). Variation may be maintained or increased if gene flow and or mutation add new genotypes to a population over long period of time. Given the asexual reproductive system of $D$. asper; it is more than likely that genetic diversity among different populations will be low. Genetic diversity that exists among populations is the most likely originated from mutation due to adaptation to the local habitat. In contrast, temperate bamboo such as Sasamorpba borealis which is windpollinated was reported to have high genetic diversity, $\mathrm{H}=0.46$ (Lee and Chung, 1999).

The proportion of distinguishable genets $(G / N)$ varied between population, the average value is 0.68 . This is similar to a study on clonal species Vaccinium stamineum $\mathrm{L}$ (Kreher et al, 2000), but relatively high compared with values for allozyme studies of other clonal plants (Ellstrand and Roose, 1987). In general, molecular markers such as RAPDs give results consistent to isozymes or show greater variation. The Simpson's diversity index revealed that most of the populations have unique genotype (value $=0$ means the population composed of a single genet, value $=1$ means every sampled plant has a unique genotype), the lowest diversity index is population Kuningan, West Java.

The UPGMA cluster analysis revealed five main clusters: Kulonprogo one cluster; Sleman, Lamongan, Ngawi, Sukabumi and Pandeglang in one cluster; Temanggung, Kuningan and Ambarawa in one cluster; Banyuwangi and Sumedang in one cluster and Purwokerto one cluster. These clustering, however, do not reflect geographical distribution.

\section{CONCLUSION}

Several conclusions may be drawn from the present study, namely:

1. The genetic diversity of $D$. asper revealed by RAPD markers shows that is relatively low ( $\mathrm{He} 0.040)$. The total number of multi-locus genotypes in all populations ranged from 3 to 9 (mean 6.5), indicating that all populations consisted of multiple genotypes.

2. As a asexually propagated plant, population of $D$. asper from different geographic origin has unique genotype, as indicated by the high value of Simpson's diversity index.

3. There was no geographical grouping of the populations in relation to its genetic distance. 


\section{Acknowledgements}

The author would like to thank the International Genetic Resources Institute (IPGRI) for the research grant APO 03/095 and to the Centre for Biotechnology and Tree Improvement for facilities to carry out this study. The author also acknowledged the contribution of Charomaini for collecting the germplasm and establishing the conservation plot, and Suharyanto for his assistance with the laboratory work. Thanks also due to A. Widyatmoko for comments on the manuscript.

\section{REFERENCES}

Dransfield, S. and E.A. Widjaja (Eds.). 1995. Bamboos. Plant Resources of South-East Asia. No.7. Bogor, Indonesia.

Ellstrand, N.C. and M.L. Roose. 1987. Patterns of genotypic diversity in clonal plant species. American Journal of Botany 74: 123-131.

Ellstrand, N.C. and D.R. Elam. 1993. Population genetic consequences of small population size:implications for plant conservation. Annual Review of Ecology and Systematics, 24:219-242.

Hamrick, J.L. and M.J.W. Godt. 1989. Allozyme diversity in plant species. In A.H.D. Brown, M.T. Clegg, A.L. Kahler and B.S. Weir (eds.). Plant Population Genetics, Breeding and Genetic Resources. Sinaeur Associates, Sunderland, Massachusetts. Pp: 43-63.

Hamrick, J.L., MJW. Godt and SL. Sherman-Broyles. 1992. Factor influencing levels of genetic diversity in woody plant species. New Forests 6:95-124.

Jover, M.A., L. Castillo-Agudo, M. Garcia-Carrascosa, and J. Segura. 2003. Random amplified polymorphic DNA assessment of diversity in western Mediterranean populations of the seagrass Posidonia oceanica. American Journal of Botany 90(3): 364-369.

Kreher, S.A., S.A. Fore and B.S. Collins. 2000. Genetic variation within and among patches of the clonal species, Vaccinium stamineum L. Molecular Ecology 9: 1247-1252.

Lee, N.M. and M.G. Chung. 1999. High levels of genetic variation in Korean populations of Sasamorpha borealis (Poaceae). Bot. Bull. Acad.Sin. 40:311-317.

Lee, S.L., R. Wickneswari, M.C. Mahani and A.H. Zakri. 2000. Genetic diversity of a tropical tree species, Shorea leprosula Miq. (Dipterocarpaceae), in Malaysia: Implications for conservation of genetic resources and tree improvement. Biotropica 32(2): 213-224.

Murawski, D.A. and J.L. Hamrick. 1990. Local genetic and clonal structure in the tropical terrestrial bromeliad, Aechemea magdalenae. American Journal of Botany 77:86-89.

Murray, M.G. and W.F. Thompson. 1980, Rapid isolation of high molecular weight plants DNA. Nucleic Acid Research. 8:4321-4325.

Ne1, M. 1972. Genetic distance between populations. American Naturalist 106: 283-292. 
1973. Analysis of gene diversity in sub-divided populations. Proceedings of the National Academy of Science 70: 3321-3323.

1977. F-statistics and analysis of gene diversity in sub-divided populations. Annual of Human Genetics 41: 225-233.

Pielou, C.E. 1969. An introduction to mathematical ecology. Wiley-Interscience, New York, $327 \mathrm{p}$.

Sipes, S.D. and P.G. Wolf. 1997. Clonal structure and patterns of allozyme diversity in the rare endemic Cycladenia butmilis vat. jonesii (Apocynaceae). American Journal of Botany 84: 401-409.

Shiraishi, S. and A. Watanabe. 1995. Identification of chloroplast genome between Pinus densiflora SIEB et ZUCC and $P$. thunbergii PARL based on the polymorphism in rbcL gene. Journal Japan Forest Society 77:429-436.

Williams, J.G.K., A.R. Kubelik, K.J. Livak, J.A. Rafalski and S.V. Tingey. 1990. DNA polymorphisms amplified by arbitrary primers are useful as genetic markers. Nucelic Acids Research 18: 6531-6535.

Yeh, F.C., R.C. Yang and T. Boyle. 1993. POPGENE Version1.3.1. Microsoft Window-based Freeware for Population Genetic Analysis. University of Alberta, Canada.

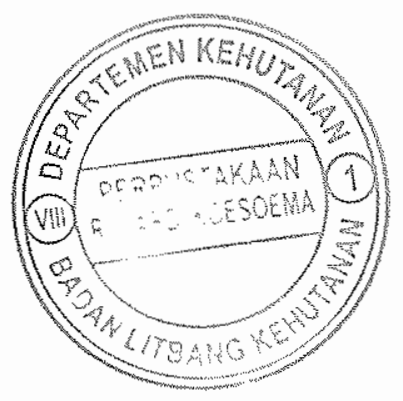

